\title{
Variability in size-selective mortality obscures the importance of larval traits to recruitment success in a temperate marine fish
}

Hannah M. Murphy ${ }^{1,2^{*}}$, Fletcher W. Warren-Myers ${ }^{1,2}$, Gregory P. Jenkins ${ }^{1}$, Paul A. Hamer ${ }^{3}$, Stephen E. Swearer ${ }^{1}$

${ }^{1}$ Department of Zoology, University of Melbourne, Parkville, Victoria, Australia 3010

${ }^{2}$ Victorian Marine Science Consortium, PO Box 114, Queenscliff, Victoria, Australia 3225

${ }^{3}$ Fisheries Victoria, Department of Environment and Primary Industries, PO Box 114, Queenscliff, Victoria, Australia 3225

*Email: Hannah.Murphy@mi.mun.ca

Contact number of H. Murphy: +1 7097780374

Current address of H. Murphy: Centre for Fisheries Ecosystems Research, Fisheries and Marine Institute, Memorial University of Newfoundland, P.O. Box 4920, St. John's, NL, Canada, A1C $5 \mathrm{R} 3$ 


\begin{abstract}
In fishes, the growth-mortality hypothesis has received broad acceptance as a driver of recruitment variability. Recruitment is likely to be lower in years when the risk of starvation and predation in the larval stage is greater, leading to higher mortality. Juvenile snapper, Pagrus auratus (Sparidae), experience high recruitment variation in Port Phillip Bay, Australia. Using a five-year $(2005,2007,2008,2010,2011)$ data set of larval and juvenile snapper abundances and their daily growth histories, based on otolith microstructure, we found selective mortality acted on larval size at five days post hatch in four low and average recruitment years. The highest recruitment year (2005) was characterised by no size-selective mortality. Larval growth of the initial larval population was related to recruitment, but larval growth of the juveniles was not. Selective mortality may have obscured the relationship between larval traits of the juveniles and recruitment as fast-growing and large larvae preferentially survived in lower recruitment years and fast growth was ubiquitous in high recruitment years. An index of daily mortality within and among three years $(2007,2008,2010)$, where zooplankton were concurrently sampled with ichthyoplankton, was related to per capita availability of preferred larval prey, providing support for the match-mismatch hypothesis. In 2010, periods of low daily mortality resulted in no selective mortality. Thus both intra- and inter-annual variability in the magnitude and occurrence of selective mortality in species with complex life cycles can obscure relationships between larval traits and population replenishment, leading to underestimation of their importance in recruitment studies.
\end{abstract}

Key words: early life history; match-mismatch hypothesis; snapper; Pagrus auratus; recruitment dynamics

Running title: Size-selective mortality obscures larval traits 


\section{Introduction}

Many organisms have complex life cycles, where individuals undergo ontogenetic transformation (metamorphosis) from a larval to juvenile life stage (Wilbur 1980). Larval sizeat-age, growth, and condition have been found to influence growth and development of subsequent life stages in insects, marine invertebrates, fishes, and amphibians (McCormick and Hoey 2004; Van Allen et al. 2010; Crean et al. 2011; Hellmann et al. 2011). For most marine fishes, which are characterised by high fecundity and a pelagic larval stage with high mortality rates, timing reproduction to coincide with periods of abundant prey is thought to be critical for larvae to maximise their chances of survival to the juvenile stage (i.e. the match-mismatch hypothesis; Cushing 1972, 1990). Furthermore, variation in prey availability can lead to variation in larval growth and performance facilitating selective mortality on these phenotypic traits for both the larval and subsequent ontogenetic stages (Sogard 1997; Searcy and Sponaugle 2001; Vigliola and Meekan 2002; Gagliano et al. 2007).

Marine fishes experience very high mortality in early life (Bailey and Houde 1989). Mortality is often selective, preferentially removing smaller and slower-growing individuals within cohorts (Meekan and Fortier 1996; Hare and Cowen 1997; Meekan et al. 2006), although some studies have found larger and faster-growing larvae to be more vulnerable to predation than smaller, slow-growing individuals (Biro et al. 2004; Sponaugle et al. 2011), and others have found no evidence of selective mortality (Bertram and Leggett 1994; Robert et al. 2010). The growth-mortality hypothesis (Cushing 1975; Anderson 1988) predicts that fast growth of larvae should result in their higher survival probability and higher recruitment of young fish to populations. Fast growth detected in a larval cohort can, however, be a reflection of either most larvae encountering ideal foraging and temperature conditions or selective mortality by predation 
and/or starvation removing slow-growing individuals prior to sampling (Meekan and Fortier 1996; Robert et al. 2007). Therefore, demonstrating selective mortality by comparing growth parameters among larval cohorts or using the larval characteristics of juveniles to investigate selective mortality can be problematic.

Comparisons of larval growth parameters within cohorts of the initial larval stages with those of survivors to later life stages can more clearly demonstrate the importance of selective mortality (Meekan et al. 2006; Robert et al. 2007; D'Alessandro et al. 2013). Selective mortality is more likely to occur in years of poor conditions for larval growth because in good years, with optimum temperature and prey availability, variability in larval traits is low and most larvae do well (Sogard 1997; Meekan et al. 2006). While recent research has emphasised the importance of larval traits and selective processes on the survival of individuals post-settlement (Robert et al. 2007; Grorud-Colvert and Sponaugle 2010; Islam et al. 2010), the importance of selective mortality can vary through time (Gagliano et al. 2007) and among populations of a species (Searcy and Sponaugle 2001). Thus, long-term datasets are needed to provide insight into if and why selective mortality varies interannually and how this variability can affect recruitment dynamics and our understanding of recruitment processes (Robert et al. 2007; Rankin and Sponaugle 2011).

Snapper, Pagrus auratus (Sparidae) (formerly Chrysophrys auratus) is a highly exploited temperate marine fish species with high recruitment variability (Fowler and Jennings 2003; Hamer and Jenkins 2004; Zeldis et al. 2005). Snapper can live to at least 40 years, reach sexual maturity at four to six years, and are highly fecund, multiple batch spawners with a pelagic larval duration estimated to be 18-28 days and settlement at 10-12 mm SL (Battaglene and Talbot 1992; Scott et al. 1993; Francis 1994a; Coutin et al. 2003; Fowler and Jennings 2003). Recent 
research indicates that variations in survival in the larval stage drives interannual variation in recruitment of juveniles (0-age) in this species (Fowler and Jennings 2003; Zeldis et al. 2005; Hamer et al. 2010). Furthermore, in Port Phillip Bay (PPB), south-eastern Australia, a recent study indicates that in lower recruitment years snapper larvae experience slow growth which has been related to lower densities of Paracalanus sp. and Acartia sp. nauplii and lower temperatures, which is consistent with the hypothesis that cohorts experiencing higher predation and starvation rates through poor feeding conditions and slow growth result in lower recruitment (Murphy et al. 2013).

To test the hypothesis that selective mortality occurs more often in lower recruitment years than higher recruitment years, we use otolith microstructure to estimate cumulative size at 5 days post hatch (dph) of both the larval and juvenile stages of snapper for five year-classes that have variable recruitment strengths $(2005,2007,2008,2010,2011)$ from 6 areas around PPB, and for three cohorts from one area in one average recruitment year (2010). We test if selective mortality obscures the relationship between larval traits and recruitment by relating larval growth of the larval and juvenile life stages (5 larval year-classes and 12 juvenile year-classes) to interannual variation in recruitment. We are also interested in how prey availability may be a potential driver of mortality, so we compare intra- and inter-annual variability in daily mortality to per capita prey availability in years where we sampled zooplankton concurrently with ichthyoplankton $(2007,2008,2010)$. 


\section{Methods}

Field sampling

Over seven years (2005-2011), ichthyoplankton were sampled during daylight hours from late November to early January at six areas within PPB, Australia (Fig. 1). Each area was sampled on at least two occasions in each year, with one sampling time in late November/early December and one sampling time in late December/early January. The sampling period was chosen to overlap with the expected peak spawning and larval growth period for snapper in Victoria based on previous gonadosomatic index, daily ageing and larval abundance data (Jenkins 1986; Coutin et al. 2003; Hamer et al. 2011). In addition to the bay-wide sampling, high-frequency sampling was conducted at one area (Carrum) every week from 17 November 2009 to 5 January 2010 (8 weeks).

Detailed information on the sampling method can be found in Hamer et al. (2011). Briefly, on each sampling occasion, five randomly placed, stepped oblique plankton tows were used to sample the entire water column (depth range of 6 - $25 \mathrm{~m}$ ) at each area. Ichthyoplankton samples were collected using a $500 \mu \mathrm{m}$ mesh plankton net with a circular mouth of $80 \mathrm{~cm}$ diameter. Material from the cod-end was filtered through a $500 \mu \mathrm{m}$ mesh sieve and immediately preserved in $95 \%$ ethanol.

Zooplankton were sampled from 2007 to 2011 during the bay-wide sampling (results presented in Murphy et al. (2012)). During the high-frequency sampling at Carrum in 2010, similar methods were used. Briefly, three zooplankton samples were collected on each of the eight sampling dates, using a zooplankton net with a mouth diameter of $0.3 \mathrm{~m}$ and mesh size of $80 \mu \mathrm{m}$. A General Oceanics Flowmeter (Model \# 2030R) was attached to the mouth of the net to standardise for catch per unit effort. Zooplankton tows lasted $\sim 2$ minutes and surveyed the 
entire water column by running the zooplankton net up and down a guide rope connected to the ichthyoplankton net when the net was sampling its deepest step $1 \mathrm{~m}$ above the sea floor.

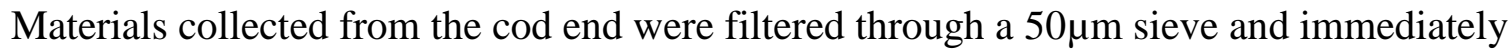
preserved in $4 \%$ buffered formalin in seawater.

The same six areas that were sampled for ichthyoplankton within PPB were sampled for juvenile snapper (< 5 months of age) from late March to early April over 12 years (2000-2011) (Fig. 1). The juvenile snapper recruitment index is based on densities (catch per unit area) of juvenile snapper sampled by a small beam trawl in annual surveys since 2000, so our categorisation of low, average and high recruitment is relevant to the 12-year dataset and may not be representative of historical levels of recruitment (Hamer and Jenkins 2004; Kemp et al. 2012). For more details on sampling of juvenile snapper refer to Hamer and Jenkins (2004). Briefly, sampling was conducted with a plumb-staff beam trawl (2.8 m mouth width) (Hamer and Jenkins 2004). Sampling was done to maximise catch rates (Hamer et al. 1998). Each sampling event consisted of five non-overlapping trawls of 350-500 m of bottom contact with 710 min bottom time within each site (Hamer and Jenkins 2004). All juvenile snapper were sorted from the net immediately after net retrieval and frozen for later measurement and otolith removal.

Laboratory methods

Snapper larvae and small juveniles have previously been shown to deposit one increment per day (Fowler and Jennings 2003). Larval otoliths were immersed in immersion oil and viewed whole under a compound microscope (Olympus BX-51) at 1000x magnification. Daily increments were enumerated and measured as previously described in Murphy et al. (2013).

The sagittal otoliths from the juveniles were cleaned of adhering tissue, air dried for 24 
hours, and stored in plastic vials until mounting. The otoliths were mounted on glass slides using Crystalbond $^{\mathrm{TM}}$, ground in the transverse plane using wetted 800-1200 grit abrasive paper and polished with nine and three $\mu \mathrm{m}$ imperial diamond lapping film by hand until close to the core. The thickness of the sectioned otolith was approximately $50 \mu \mathrm{m}$. Each sectioned sagitta was examined using a compound microscope (Olympus BX-51) at magnification 200-400x with an attached video camera. Pre-settlement increments were counted and increment widths were measured from the primordium to the settlement mark (i.e. Fowler and Jennings 2003) using ImagePro Plus ver. 6.3 software. After the settlement mark, the increments were counted to the proximal margin along the dark band referred to as the sagittal-subcupular meshwork fibre zone (Francis 1994b). Hatch dates of juveniles were back-calculated and compared with those of the initial larval population to ensure that the hatch date period of the juvenile and larval stages overlapped.

Larval increment widths were measured in the sagittal plane, while juvenile snapper presettlement increment widths were measured in the transverse plane. In 2010, juvenile presettlement increment widths were measured in both the transverse and sagittal planes. Using paired t-tests for each of the first nine increment widths measured in both the sagittal and transverse planes in sister otoliths $(n=24)$, there was no significant difference in mean width for any increment $(p>0.20)$. Therefore, it was appropriate to compare larval growth measured in the sagittal plane for whole larval otoliths with larval growth of juveniles measured in the transverse plane of sectioned otoliths.

Data analysis

Size and growth measurements based on otolith microstructure were used to investigate the occurrence of selective mortality (e.g. Campana 1996). Larvae and juveniles from the high- 
frequency sampling were pooled into three intra-annual cohorts based on estimated hatch dates (early cohort: 17 November to 5 December; middle cohort: 6 - 15 December; late cohort: 16 December to 5 January) due to low larval numbers. The majority of sampled larvae were young ( $87 \%$ of larvae $<10 \mathrm{dph}$ ), so, to include as many larvae in the analysis as possible, a two factor ANCOVA with cohort (early, middle, late) and life-stage (larvae and juvenile) was used to test for size-selective mortality at $5 \mathrm{dph}$, with temperature as a covariate. Since we were testing for selective mortality in the first week of development (first-feeding stage), we also tested for the potential importance of maternal effects on larval survival by using larval size-at-hatch (distance from the core of the otolith to the first increment) in a two factor (lifestage and cohort) ANOVA. Mean temperature during the sampling period, based on daily temperatures obtained from a fixed temperature logger at area HB deployed at three meter depth by Fisheries Victoria Research Branch, Queenscliff Centre, ranged from $18-21^{\circ} \mathrm{C}$.

Similar tests to those used for intra-annual selective mortality were used to investigate if interannual size-selective mortality was acting in this population. A two-factor ANCOVA with year $(2005,2007,2008,2010,2011)$ and life-stage (larvae and juvenile) was used to test for sizeselective mortality at $5 \mathrm{dph}$, with temperature as a covariate. We pooled for sampling time and area due to low larval sample numbers at areas outside of C, F, M. Mean temperature during the sampling period ranged from $17-21^{\circ} \mathrm{C}$ (Murphy et al. 2013). A two-factor ANOVA (year and life-stage) of size-at-hatch was used to test for maternal effects on survival.

To test if larval growth was a predictor of recruitment strength and if selective mortality changed or obscured this potential relationship, we used linear regressions between mean otolith growth of the initial larval stages over the first $8 \mathrm{dph}$ and recruitment strength, and between mean otolith growth over the first 8 dph of the surviving juveniles and recruitment strength. 
The larvae and juveniles that were aged from 2007, 2008, and 2010 were binned into discrete $10 \mathrm{~d}$ cohorts based on estimated hatch dates (1 November to 8 February, cohorts A - J) and areas (F, C, M, HB, CB, PW) to test for the occurrence of prey-dependent mortality. An estimated hatch date was calculated for un-aged larvae and juveniles from the slope of the regression of length vs age at capture for each year and life-stage (Murphy et al. 2013; Table 1). These three years were used due to availability of both sufficient larval and juvenile numbers and zooplankton samples. For the high-frequency sampling in 2010 at area C, larvae were also binned into $10 \mathrm{~d}$ cohorts based on estimated hatch dates. The sampling methods (and therefore catch rate standardisations), by necessity, were different for the larval and juvenile life stages, so larval density $\left(\mathrm{m}^{-3}\right)$ was converted to an abundance measure $\left(\mathrm{m}^{-2}\right)$ by multiplying larval density in each tow by depth of the water column (m). An index of daily mortality between the larval and juvenile stages was calculated based on Ricker (1975) for each area.

Index of Daily Mortality $=\ln ($ larval abundance $)-\ln ($ juvenile abundance) $) /$ number of days between sampling at each area

Only the availability of zooplankton that were preyed on by snapper larvae were related to daily mortality (Murphy et al. 2012): Acartia sp. and Paracalanus sp. nauplii and copepodites, cladocerans (three genera: Penilia, Podon, Evadne), and bivalve veligers. Preferred prey abundance was calculated as preferred prey density $\left(\mathrm{m}^{-3}\right)$ multiplied by depth of tow (m). Preydependent mortality was estimated by relating the index of daily mortality of each cohort to per capita preferred prey availability (preferred prey abundance per tow $\left(\mathrm{m}^{-2}\right) /$ number of larvae sampled per tow) using a linear regression.

To test if the magnitude of selective mortality was related to the index of daily mortality, the strength of selective mortality was estimated by subtracting mean larval and juvenile 
cumulative size at $5 \mathrm{dph}$ at each area in the interannual sampling and relating this measure of selective mortality to the index of daily mortality.

Otolith growth, cumulative size, size-at-hatch and larval and juvenile densities were logtransformed to meet assumptions of normality and homogeneity of variance. SYSTAT 12 was used for all statistical analyses. 


\section{Results}

Size-selective mortality

Juveniles had larger cumulative size at $5 \mathrm{dph}$ compared to the initial larval population (ANCOVA: $\mathrm{F}_{1,151}=41.23 ; \mathrm{p}<0.001$ ) in the high-frequency sampling at $\mathrm{C}$ area in 2010 , with no difference among cohorts (ANCOVA: $\left.\mathrm{F}_{2,151}=0.05 ; \mathrm{p}=0.949\right)$ (Fig. $2 \mathrm{a}$ ). Temperature was a non-significant covariate (ANCOVA: $\mathrm{F}_{1,151}=0.16 ; \mathrm{p}=0.687$ ). Juveniles were also larger at hatch than the initial larval population (ANOVA: $\mathrm{F}_{1,166}=20.08, \mathrm{p}<0.001$ ) at $\mathrm{C}$ area in 2010, with no difference among cohorts (ANOVA: $\left.F_{2,166}=2.47, p=0.084\right)$ (Fig. 2 b).

For the interannual sampling, ANCOVA of cumulative size at 5 dph of the initial larval stages and the juveniles found a significant interaction between years and life-stages $\left(\mathrm{F}_{4,457}=\right.$ 12.98; $\mathrm{p}<0.001)$. The temperature covariate was non-significant $\left(\mathrm{ANCOVA}_{1,455}=0.16 ; \mathrm{p}=\right.$ 0.693). When considering each year separately, size-selective mortality was found in the four low and average recruitment years: $2007\left(\mathrm{~F}_{1,55}=40.25 ; \mathrm{p}<0.001\right), 2008\left(\mathrm{~F}_{1,64}=33.54 ; \mathrm{p}<\right.$ 0.001), $2010\left(\mathrm{~F}_{1,216}=46.15 ; \mathrm{p}<0.001\right)$, and $2011\left(\mathrm{~F}_{1,28}=5.31 ; \mathrm{p}=0.029\right)$, with juveniles larger at 5 dph compared to the initial larval stages (Fig. 3 a). In 2005, the highest recruitment year, there was minimal difference in larval cumulative size at $5 \mathrm{dph}$ between the juveniles and the initial larval stages $\left(\mathrm{F}_{1,93}=0.34 ; \mathrm{p}=0.561\right)($ Fig. $3 \mathrm{a})$.

For the interannual sampling, there was an interaction between life-stage and year for size-at-hatch (two factor ANOVA: $\mathrm{F}_{4,500}=4.99, \mathrm{p}=0.001$ ), with larvae from the initial population in 2010 being significantly smaller at hatch than the juveniles (Post hoc Tukey's: p < 0.001) (Fig. 3 b).

There was a positive linear relationship between recruitment strength and larval growth of the initial larval population $\left(y=0.04 x-0.09, r^{2}=0.90, p=0.013, n=5\right)($ Fig. 4 a), but not 
between recruitment strength and larval growth of the surviving juveniles (Fig. 4 b). Prey-dependent mortality

For the interannual bay-wide sampling, the majority of larvae and juveniles were sampled in the three eastern areas: C, F, M (Fig. 1). In 2007, there were five cohorts from F, C areas; in 2008, there were 11 cohorts from F, C, M areas; and in 2010, there were 10 cohorts from F, C, M areas (Fig. 1). In 2007 the mean index of mortality across cohorts and areas was 0.044 (range 0.033 at $\mathrm{F}$ for cohort 4 to 0.051 at $\mathrm{F}$ for cohort 5 ); in 2008 , the mean index of mortality was 0.040 (range 0.022 at $\mathrm{F}$ for cohort 3 to 0.055 at $\mathrm{C}$ for cohort 5); and in 2010 the mean index of mortality was 0.054 (range 0.022 at $\mathrm{F}$ for cohort 5 to 0.080 at $\mathrm{C}$ for cohort 5). Per capita prey availability was negatively related to the index of mortality $\left(y=-0.01 x+0.08, r^{2}=0.35, p=\right.$ $0.001, \mathrm{n}=26$ ) (Fig. 5 a). For the high-frequency sampling at area $\mathrm{C}$ in 2010 , there were five $10 \mathrm{~d}$ cohorts based on estimated hatch dates. The mean index of daily mortality was 0.068 (range: 0.02 to 0.08 ). At area $\mathrm{C}$ in 2010 per capita prey availability was negatively related to mortality (y $\left.=-0.01 x+0.12, r^{2}=0.98, p=0.002, n=5\right)($ Fig. $5 b)$.

The magnitude of selective mortality (indicated by the difference between mean larval and juvenile cumulative size at $5 \mathrm{dph}$ ) was negatively related to the index of mortality in 2010 (y $\left.=-108.98 \mathrm{x}+4.60, \mathrm{r}^{2}=0.82, \mathrm{p}=0.001, \mathrm{n}=9\right)($ Fig. 6$)$, indicating that selective mortality was higher in cohorts that experienced higher daily mortality. In 2007 and 2008, there was no relationship between the magnitude of selective mortality and daily mortality. 


\section{Discussion}

Size-selective mortality

Recruitment strength of snapper is related to interannual variation in growth of the initial larval stages, while larval growth measured in the juvenile recruits is not. The lack of relationship between larval growth measured from juvenile otoliths and recruitment variation appears to be due to the variable occurrence of selective mortality acting early in larval development, with size-selective mortality resulting in larger and faster-growing larvae preferentially surviving in some low and average recruitment years. Slow-growing and small larvae from low and average recruitment years may have had a higher risk of mortality by starvation and/or predation due to delayed development (i. e. Anderson 1988). In the one high recruitment year, there is no evidence of selective mortality. Larval growth and size may not have been an important driver of larval survival in the high recruitment year because the majority of larvae may have experienced similar optimal growth conditions. Furthermore, because snapper larvae from high recruitment years have fast growth, larval growth histories of juveniles from high and low recruitment years are similar even though recruitment varied. Numerous studies have used larval traits of survivors (i.e. competent larvae, settlers, juveniles) rather than the early larval stages to relate to recruitment dynamics (e.g. Raventos and Macpherson 2005; Rankin and Sponaugle 2011; Smith and Shima 2011). Our results suggest such an approach may obscure the importance of selective mortality during early larval development as a driver of recruitment dynamics.

Intra-annual size-selective mortality is detected in 2010 by using high-frequency sampling. Larvae from the initial cohorts (early, middle, late), are smaller than the surviving juveniles at $5 \mathrm{dph}$, which corresponds with the results from the broad-scale sampling in 2010. 
The broad-scale sampling, therefore, is able to detect the occurrence of selective mortality, even though larval cohorts can be lost quickly from the population. A previous study found that $98 \%$ of snapper larvae die between hatch and $8 \mathrm{dph}$ (Zeldis et al. 2005). Due to this high mortality rate, larval traits of the initial stages need to be considered in recruitment studies as late-stage larvae and juveniles most likely represent only a small subset of the initial larval traits.

Selective mortality occurs early in development, which is consistent with other studies (e.g. Meekan et al. 2006). However, selective mortality can be important throughout the larval period (Hare and Cowen 1997), at different larval developmental periods in different years (Robert et al. 2007), and in the juvenile or post-settlement stage (Sogard 1997; Joh et al. 2013). The sampling methods used here are biased against yolk-sac and late-stage pre-settlement larvae (e. g. Zeldis et al. 2005), so we are not able to determine if and how selective mortality influences survival across the entire larval developmental period. However, the occurrence of size-selective mortality in the first week post-hatch indicates that mortality processes operating very early in the life history appear to be critically important drivers of recruitment variation for snapper in PPB.

The only year where there is evidence of selective mortality acting on size-at-hatch is in 2010, with juveniles larger at hatch than the initial larval population. Maternal effects can potentially extend beyond hatching and have an effect on larval size and growth (Chambers and Waiwood 1996; Marteinsdottir and Steinarsson 1998; Green and McCormick 2005). However, the influence of size-at-hatch on larval survival may decrease throughout ontogeny as predation, prey availability, and foraging ability of larvae become more important (Kamler 2005), which may be the case for snapper as recruitment is average in 2010. Since selection for size-at-hatch is not seen in any of the other sampled years, maternal effects may not play an important role in 
snapper recruitment dynamics, although research into interannual variation in egg densities, egg quality, and spawner fitness would be required to fully evaluate the importance of maternal effects on snapper recruitment dynamics.

Prey-dependent mortality

Mortality of snapper early life stages varies both within and among years. Furthermore, variance in the index of daily mortality is related to per capita larval prey availability, with higher mortality in cohorts that encounter lower per capita prey availability. The link between mortality and prey provides compelling support for the match-mismatch hypothesis. Furthermore, daily mortality has a strong influence on the magnitude of selective mortality in 2010. At least in this year, cohorts that experience higher mortality rates suffer greater selective mortality, suggesting that small larvae are more vulnerable to starvation and/or predation when food is limited. For our mortality analysis, we assume that there is minimal movement of juveniles among areas. In Shark Bay, Western Australia, there is evidence of meso-eddies retaining snapper eggs and larvae in isolated spawning areas and high site fidelity of snapper juveniles and sub-adults (Bastow et al. 2002; Gaughan et al. 2003; Nahas et al. 2003). In PPB, hydrodynamic modelling indicates there is high retention of snapper larvae in the east of the bay where we sampled the majority of larvae and juveniles, which suggests similar localised retention may be occurring in PPB (Black et al. 1993; Jenkins and Hatton 2007).

Low prey availability may have influenced larval mortality directly through starvation (Tanaka et al. 2008) or indirectly through predation, influenced by larval size-at-age and growthrate (Houde 1987; Anderson 1988). While no data are available on the potential predators of snapper larvae, the co-occurrence of anchovy eggs and larvae with snapper larvae in the ichthyoplankton samples suggests that adult anchovies, a planktivorous predator, are present in 
PPB at the same time as snapper larvae (Jenkins 1986). Furthermore, several species of scyphomedusa are also present in the plankton samples and have previously been shown to be predators of fish eggs and yolk-sac larvae in PPB (Fancett and Jenkins 1988). Although it is not possible to determine whether the cause of mortality is predation or starvation, the consistent relationship between prey availability and mortality across three years suggests that the dynamics of the match-mismatch between prey availability and larval occurrence plays an important role in influencing snapper recruitment dynamics in PPB.

Conclusions

Recruitment in snapper is influenced by growth-related processes operating early in life history. Our research provides insight into the drivers of larval mortality, with a strong link between preferred prey availability and mortality, as well as the mechanistic nature of selective mortality with higher mortality/lower recruitment in cohorts experiencing greater selective mortality, as seen in 2010. As the magnitude of selective mortality can vary among cohorts both within and among years, studies investigating the relationship between phenotypic traits of survivors and recruitment may underestimate the importance of early life history traits in dynamics of marine fish populations. 


\section{Acknowledgements}

We would like to acknowledge Silvana Acevedo, Dean Chamberlain, Julia Kent, Andrew Brown, Tim Kenner, Jessica Hommelhoff, Annique Harris, and Camila Martins for help in the field and laboratory. Fish Ageing Services prepared the juvenile otoliths for age analysis. The manuscript was greatly improved by the comments from two anonymous reviewers. This project was funded by an Australian Research Council Linkage Grant (LP0989432) between the Department of Primary Industries, Fisheries Victoria, and the University of Melbourne. Port of Melbourne Corporation was an additional funding source. 


\section{References}

Anderson JT (1988) A review of size dependent survival during pre-recruit stages of fishes in relation to recruitment. J. Northw. Atl. Fish. Sci. 8:55-66

Bailey KM, Houde ED (1989) Predation on eggs and larvae of marine fishes and the recruitment problem. Adv. Mar. Biol. 25:1-83

Bastow TP, Jackson G, Edmonds JS (2002) Elevated salinity and isotopic composition of fish otolith carbonate: stock delineation of snapper, Pagrus auratus, in Shark Bay, Western Australia. Mar. Biol. 141:801-806

Battaglene SC, Talbot RB (1992) Induced spawning and larval rearing of snapper, Pagrus auratus (Pisces, Sparidae), from Australian waters. N.Z. J. Mar. Freshwater Res. 26:179183

Bertram DF, Leggett WC (1994) Predation risk during the early-life history periods of fishes: separating the effects of size and age. Mar. Ecol. Prog. Ser. 109:105-114

Biro PA, Abrahams MV, Post JR, Parkinson EA (2004) Predators select against high growth rates and risk-taking behaviour in domestic trout populations. Proc. R. Soc. Lond. B Biol. Sci. 271:2233-2237. doi: 10.1098/rspb.2004.2861

Black K, Hatton D, Rosenberg M (1993) Locally and externally-driven dynamics of a large semi-enclosed bay in southern Australia. J. Coast. Res. 9:509-538

Campana SE (1996) Year-class strength and growth rate in young Atlantic cod Gadus morhua. Mar. Ecol. Prog. Ser. 135:21-26

Chambers RC, Waiwood KG (1996) Maternal and seasonal differences in egg sizes and spawning characteristics of captive Atlantic cod, Gadus morhua. Can. J. Fish. Aquat. Sci. 53:1986-2003. doi: doi:10.1139/f96-141 
Coutin PC, Cashmore S, Sivakumuran KP (2003) Assessment of the Snapper Fishery in Victoria. Marine and Freshwater Resources Institute, Queenscliff. Project No 97/127. Fisheries Research and Development Corporation. Canberra, Australia.

Crean AJ, Monro K, Marshall DJ (2011) Fitness consequences of larval traits persist across the metamorphic boundary. Evolution 65:3079-3089. doi: 10.1111/j.15585646.2011.01372.x

Cushing DH (1975) Marine ecology and fisheries. Cambridge University Press, Cambridge D'Alessandro EK, Sponaugle S, Cowen RK (2013) Selective mortality during the larval and juvenile stages of snappers (Lutjanidae) and great barracuda Sphyraena barracuda. Mar. Ecol. Prog. Ser. 474:227-242

Fancett MS, Jenkins GP (1988) Predatory impact of scyphomedusae on ichthyoplankton and other zooplankton in Port Phillip Bay. J. Exp. Mar. Biol. Ecol. 116:63-77

Fowler AJ, Jennings PR (2003) Dynamics in 0+ recruitment and early life history for snapper (Pagrus auratus, Sparidae) in South Australia. Mar. Freshwater Res. 54:941-956

Francis MP (1994a) Duration of larval and spawning periods of Pagrus auratus (Sparidae) determined from otolith daily increments. Environ. Biol. Fishes 39:137-152

Francis MP (1994b) Growth of juvenile snapper, Pagrus auratus. N.Z. J. Mar. Freshwater Res. 28:201-218

Gagliano M, McCormick MI, Meekan MG (2007) Survival against the odds: ontogenetic changes in selective pressure mediate growth-mortality trade-offs in a marine fish. Proc. R. Soc. Lond. B Biol. Sci. 274:1575-1582. doi: 10.1098/rspb.2007.0242

Gaughan D, Moran MD, Ranaldi M, Watling J (2003) Identifying nursery areas used by inner bay and oceanic snapper (Pagrus auratus) stocks in the Shark Bay region, in relation to 
the effect of prawn trawling on inner bay snapper stocks. Department of Fisheries. Fisheries and Research Development Corporation final report, project 2002/061, Perth

Green BS, McCormick MI (2005) Maternal and paternal effects determine size, growth and performance in larvae of a tropical reef fish. Mar. Ecol. Prog. Ser. 289:263-272

Grorud-Colvert K, Sponaugle S (2010) Variability in water temperature affects trait-mediated survival of a newly settled coral reef fish. Oecologia 165:675-686. doi: 10.1007/s00442010-1748-4

Hamer PA, Acevedo S, Jenkins GP, Newman A (2011) Connectivity of a large embayment and coastal fishery: spawning aggregations in one bay source local and broad-scale fishery replenishment. J. Fish Biol. 78:1090-1109

Hamer PA, Jenkins GP (2004) High levels of spatial and temporal recruitment variability in the temperate sparid Pagrus auratus. Mar. Freshwater Res. 55:663-673

Hamer PA, Jenkins GP, Acevedo S (2010) Importance of spawning in Port Phillip Bay to local snapper stocks. Fisheries Victoria Research Branch, No 37, Queenscliff, Victoria

Hamer PA, Jenkins GP, Welsford DC (1998) Sampling of newly-settled snapper, Pagrus auratus, and identification of preferred habitats in Port Phillip Bay- a pilot study. Project number 96/279. Fisheries Research and Development Corportation: Canberra, Australia

Hare JA, Cowen RK (1997) Size, growth, development, and survival of the planktonic larvae of Pomatomus saltatrix (Pisces: Pomatomidae). Ecology 78:2415-2431

Hellmann C, Winkelmann C, Worischka S, Benndorf J (2011) Extended larval development compensates for sublethal effects of fish predation in a mayfly population (Rhithrogena semicolorata, Ephemeroptera). Limnologica 41:256-265

Houde ED (1987) Fish early life dynamics and recruitment variability. American Fisheries 
Society Symposium 2:17-29

Islam MS, Ueno M, Yamashita Y (2010) Growth-dependent survival mechanisms during the early life of a temperate seabass (Lateolabrax japonicus): field test of the 'growthmortality' hypothesis. Fisher. Oceanogr. 19:230-242. doi: 10.1111/j.13652419.2010.00539.x

Jenkins GP (1986) Composition, seasonality and distribution of ichthyoplankton in Port Phillip Bay, Victoria. Aust. J. Mar. Freshwater Res. 37:507-520

Jenkins GP, Hatton D (2007) Modelling of larval King George whiting and snapper dispersal under the RL 22-m depth scenario, No. 97 Primary Industries Research Victoria, Queenscliff

Joh M, Nakaya M, Yoshida N, Takatsu T (2013) Interannual growth differences and growthselective survival in larvae and juveniles of marbled sole Pseudopleuronectes yokohamae. Mar. Ecol. Prog. Ser. 494:267-279

Kamler E (2005) Parent-egg-progeny relationships in teleost fishes: an energetics perspective. Rev. Fish. Biol. Fish. 15:399-421

Kemp J, Conron S, Hamer PA, Bruce TB, N., Brown L (2012) Victorian Snapper Stock Assessment 2011. Fisheries Victoria Assessment Report Series no. 64, Queenscliff

Marteinsdottir G, Steinarsson A (1998) Maternal influence on the size and viability of Iceland cod Gadus morhua eggs and larvae. J. Fish Biol. 52:1241-1258. doi: 10.1111/j.10958649.1998.tb00969.x

McCormick MI, Hoey AS (2004) Larval growth history determines juvenile growth and survival in a tropical marine fish. Oikos 106:225-242

Meekan MG, Fortier L (1996) Selection for fast growth during the larval life of Atlantic cod 
Gadus morhua on the Scotian Shelf. Mar. Ecol. Prog. Ser. 137:25-37

Meekan MG, Vigliola L, Hansen A, Doherty PJ, Halford A, Carleton JH (2006) Bigger is better: size-selective mortality throughout the life history of a fast-growing clupeid, Spratelloides gracilis. Mar. Ecol. Prog. Ser. 317:237-244

Murphy HM, Jenkins GP, Hamer PA, Swearer SE (2012) Interannual variation in larval survival of snapper (Chrysophrys auratus, Sparidae) is linked to diet breadth and prey availability. Can. J. Fish. Aquat. Sci. 69:1340-1351

Murphy HM, Jenkins GP, Hamer PA, Swearer SE (2013) Interannual variation in larval abundance and growth in snapper, Chrysophrys auratus Sparidae, is related to prey availability and temperature. Mar. Ecol. Prog. Ser. 487:151-162. doi: $10.3354 /$ meps 10388 .

Nahas EL, Jackson G, Pattiaratchi CB, Ivey GN (2003) Hydrodynamic modelling of snapper Pagrus auratus egg and larval dispersal in Shark Bay, Western Australia: reproductive isolation at a fine spatial scale. Mar. Ecol. Prog. Ser. 265:213-226

Rankin TL, Sponaugle S (2011) Temperature influences selective mortality during the early life stages of a coral reef fish. PLoS ONE 6:e16814

Raventos N, Macpherson E (2005) Effect of pelagic larval growth and size-at-hatching on postsettlement survivorship in two temperate labrid fish of the genus Symphodus. Mar. Ecol. Prog. Ser. 285:205-211

Ricker WE (1975) Compilation and interpretation of biological statistics of fish populations. Fisheries Research Board of Canada Bulletin 191

Robert D, Castonguay M, Fortier L (2007) Early growth and recruitment in Atlantic mackerel Scomber scombrus: discriminating the effects of fast growth and selection for fast 
growth. Mar. Ecol. Prog. Ser. 337:209-219

Robert D et al. (2010) Predation dynamics of mackerel on larval and juvenile anchovy: is capture success linked to prey condition? Fisheries Science 76:183-188. doi: 10.1007/s12562009-0205-y

Scott SG, Zeldis JR, Pankhurst NW (1993) Evidence of daily spawning in natural populations of the New Zealand snapper Pagrus auratus (Sparidae). Environ. Biol. Fishes 36:149-156. doi: 10.1007/bf00002794

Searcy SP, Sponaugle S (2001) Selective mortality during the larval-juvenile transition in two coral reef fishes. Ecology 82:2452-2470. doi: 10.1890/00129658(2001)082[2452:smdtlj]2.0.co;2

Smith AC, Shima JS (2011) Variation in the effects of larval history on juvenile performance of a temperate reef fish. Austral Ecol. 36:830-838

Sogard SM (1997) Size-selective mortality in the juvenile stage of teleost fishes: a review. Bull. Mar. Sci. 60:1129-1157

Sponaugle S, Boulay JN, Rankin TL (2011) Growth- and size-selective mortality in pelagic larvae of a common reef fish. Aquat. Biol. 13:263-273. doi: 10.3354/ab00370

Tanaka Y, Satoh K, Yamada H, Takebe T, Nikaido H, Shiozawa S (2008) Assessment of the nutritional status of field-caught larval Pacific bluefin tuna by RNA/DNA ratio based on a starvation experiment of hatchery-reared fish. J. Exp. Mar. Biol. Ecol. 354:56-64. doi: http://dx.doi.org/10.1016/j.jembe.2007.10.007

Van Allen B, Briggs V, McCoy M, Vonesh J (2010) Carry-over effects of the larval environment on post-metamorphic performance in two hylid frogs. Oecologia 164:891-898. doi: 10.1007/s00442-010-1728-8 
Vigliola L, Meekan MG (2002) Size at hatching and planktonic growth determine postsettlement survivorship of a coral reef fish. Oecologia 131:89-93

Wilbur HM (1980) Complex life cycles. Annu. Rev. Ecol. Syst. 11:67

Zeldis JR, Oldman J, Ballara SL, Richards LA (2005) Physical fluxes, pelagic ecosystem structure, and larval fish survival in Hauraki Gulf, New Zealand. Can. J. Fish. Aquat. Sci. 62:593-610 
Table 1 Recruitment index of Pagrus auratus juveniles (based on Hamer and Jenkins (2004) and Kemp et al. (2012)), juvenile length vs age relationship used in the index of daily mortality, number of juvenile otoliths aged, number of juvenile otoliths with complete pre-settlement cores used in analyses, number of larval otoliths $\geq 5$ days post hatch (dph) used in inter-annual analyses. NS (no samples)

\begin{tabular}{|c|c|c|c|c|c|}
\hline Year & $\begin{array}{l}\text { Juvenile } \\
\text { recruitment (x } \\
\left.1000 \mathrm{~m}^{-2}\right)\end{array}$ & $\begin{array}{l}\text { Juvenile } \\
\text { length vs } \\
\text { age } \\
\text { relationship }\end{array}$ & $\begin{array}{l}\text { Number of } \\
\text { juvenile } \\
\text { otoliths aged }\end{array}$ & $\begin{array}{l}\text { Number of } \\
\text { juvenile } \\
\text { otoliths used }\end{array}$ & $\begin{array}{l}\text { Number of } \\
\text { larval otoliths } \\
\text { aged }\end{array}$ \\
\hline 2000 & 0.68 & & 49 & 16 & NS \\
\hline 2001 & 7.03 & & 49 & 16 & NS \\
\hline 2002 & 1.66 & & 47 & 31 & NS \\
\hline 2003 & 1.34 & & 50 & 24 & NS \\
\hline 2004 & 12.93 & & 50 & 26 & NS \\
\hline 2005 & 4.69 & & 49 & 27 & 68 \\
\hline 2006 & 0.02 & & 5 & 2 & NS \\
\hline 2007 & 0.59 & $\begin{array}{l}\text { Age }=(T L- \\
20.39) / 0.69\end{array}$ & 48 & 14 & 42 \\
\hline 2008 & 1.88 & $\begin{array}{l}\text { Age }=(\mathrm{TL}- \\
18.82) / 0.66\end{array}$ & 49 & 16 & 50 \\
\hline 2009 & 3.13 & & 49 & 12 & NS \\
\hline 2010 & 2.31 & $\begin{array}{l}\text { Age }=(\mathrm{TL}- \\
14.71) / 0.66\end{array}$ & 49 & 27 & 191 \\
\hline 2011 & 0.17 & & 12 & 8 & 22 \\
\hline
\end{tabular}




\section{Figures}

Fig. 1 Map of PPB, Australia. Twelve years of snapper (Pagrus auratus) juvenile and six years of plankton sampling conducted at 6 areas: Carrum (C), Central Bay (CB), Frankston (F), Hobsons Bay (HB), Mordialloc (M), and Point Wilson (PW). High frequency sampling was conducted weekly from 17 November 2009 to 5 January 2010 at C

Fig. 2 For the high frequency sampling at Carrum in 2010 (a) size-selective mortality at 5 days post hatch (dph), and (b) size-at-hatch of the initial snapper larval population and juveniles. Mean \pm SE values shown. $(*)$ indicates significant differences among lifestages $(\mathrm{p}<0.05)$. Early: 17 November- 5 December 2009; middle: 6-15 December 2009; late: 16 December 2009 - 5 January 2010. Note that the scales are different. Sample sizes are indicated in bars Fig. 3 (a) Pattern of size-selective mortality at $5 \mathrm{dph}$, and (b) size-at-hatch of the initial snapper larval stages and juveniles for five year classes $(2005,2007,2008,2010,2011) .(*)$ indicates significant differences between lifestages $(\mathrm{p}<0.05)$; N.S. indicates not significant for lifestage effect. Mean \pm SE values shown. Note that the scales are different. Number of larval and juvenile otoliths analysed in each year are listed in Table 1

Fig. 4 Relationship between density of juvenile snapper (recruitment) and (a) larval growth in the first 5 dph of the initial larval stages $(n=5)$, and (b) larval growth of the juveniles $(n=12)$. Years (last two numerals) are indicated with a recruitment index (high $(\mathrm{H})$, average (A), low (L)). Note that the scales are different

Fig. 5 (a) Relationship between per capita preferred prey abundance and index of daily mortality from three years of sampling $(2007,2008,2010)(n=26)$, and (b) relationship between per capita preferred prey abundance and index of daily mortality for five $10 \mathrm{~d}$ cohorts at Carrum area in $2010(\mathrm{n}=5)$ 
Fig. 6 Relationship between magnitude of selective mortality (difference in cumulative size at 5 dph in the initial larval population and juveniles where more negative is more selective) and index of daily mortality in $2010(\mathrm{n}=9)$ 
Fig. 1

Longitude (E)

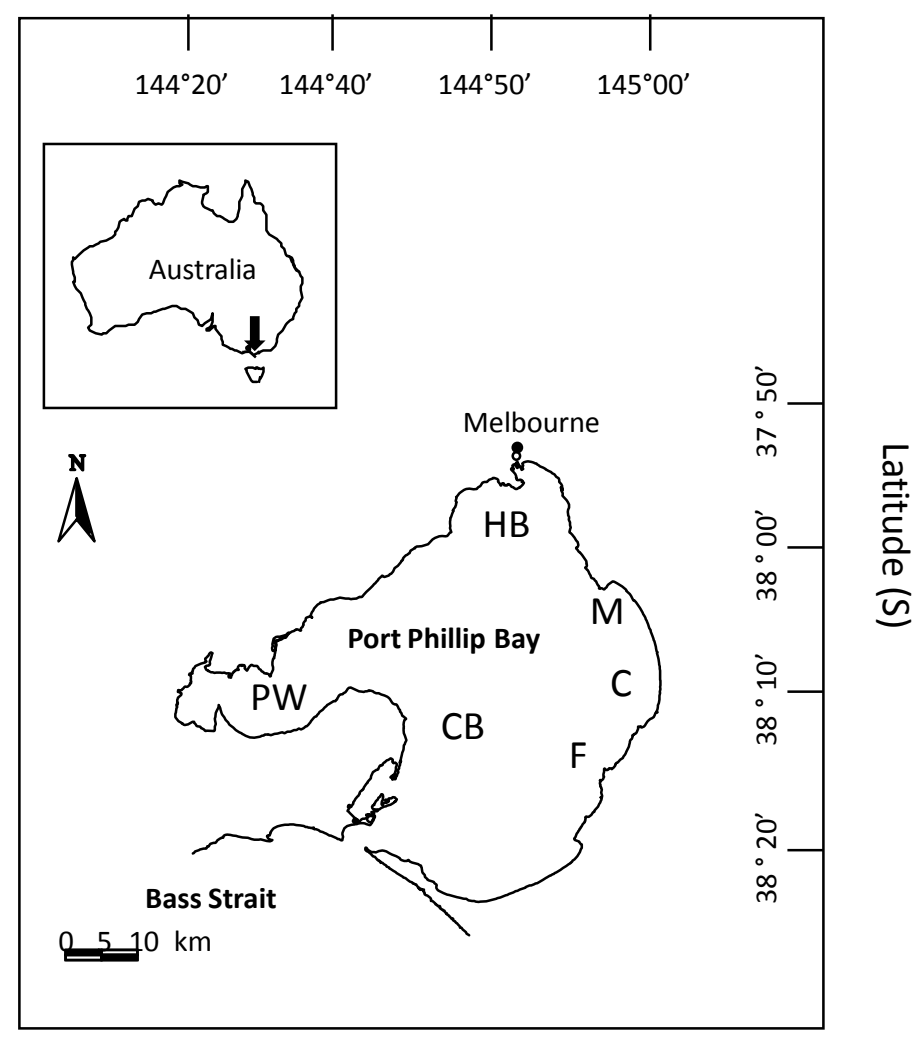


Fig. 2

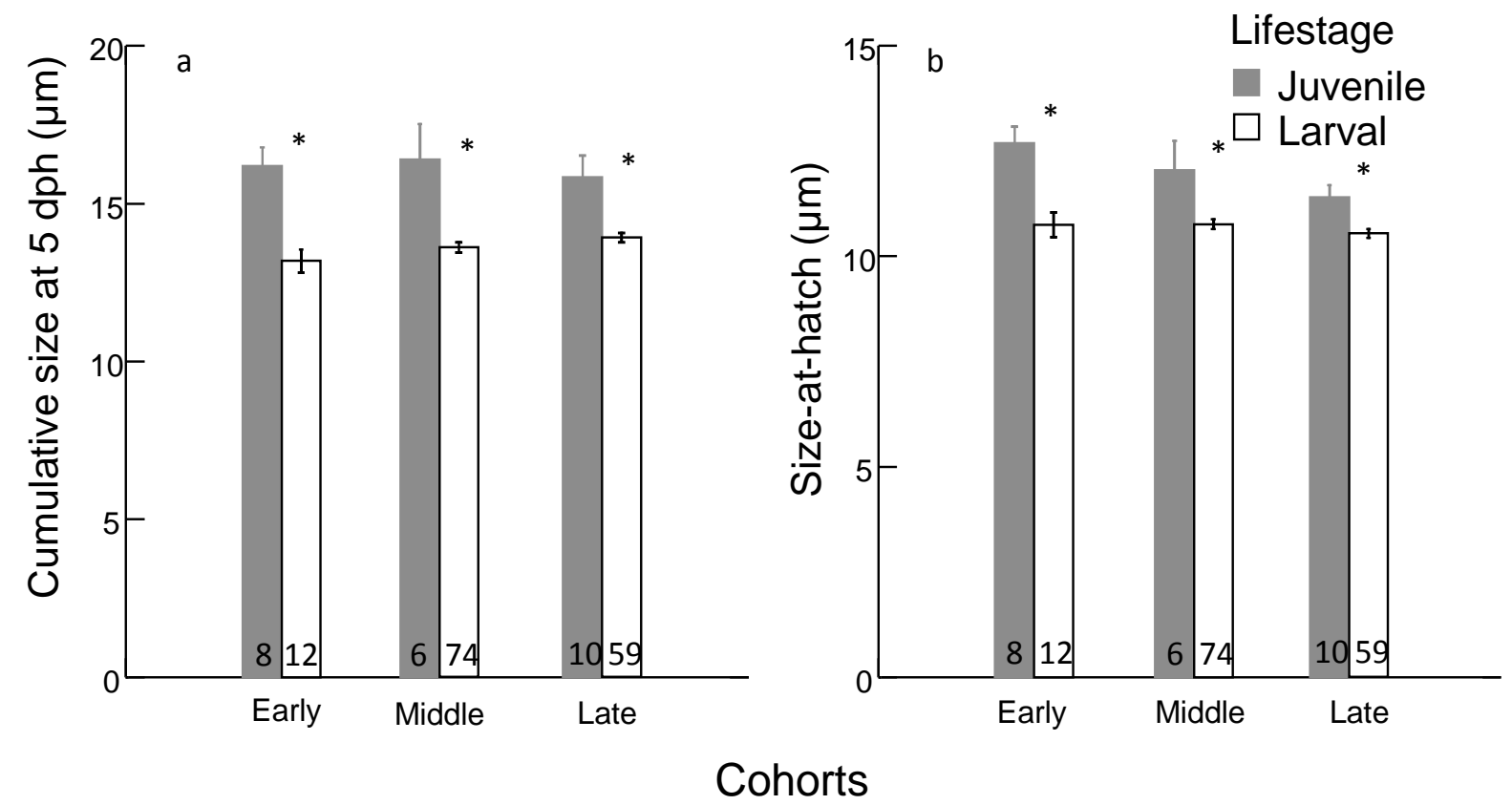


Fig. 3

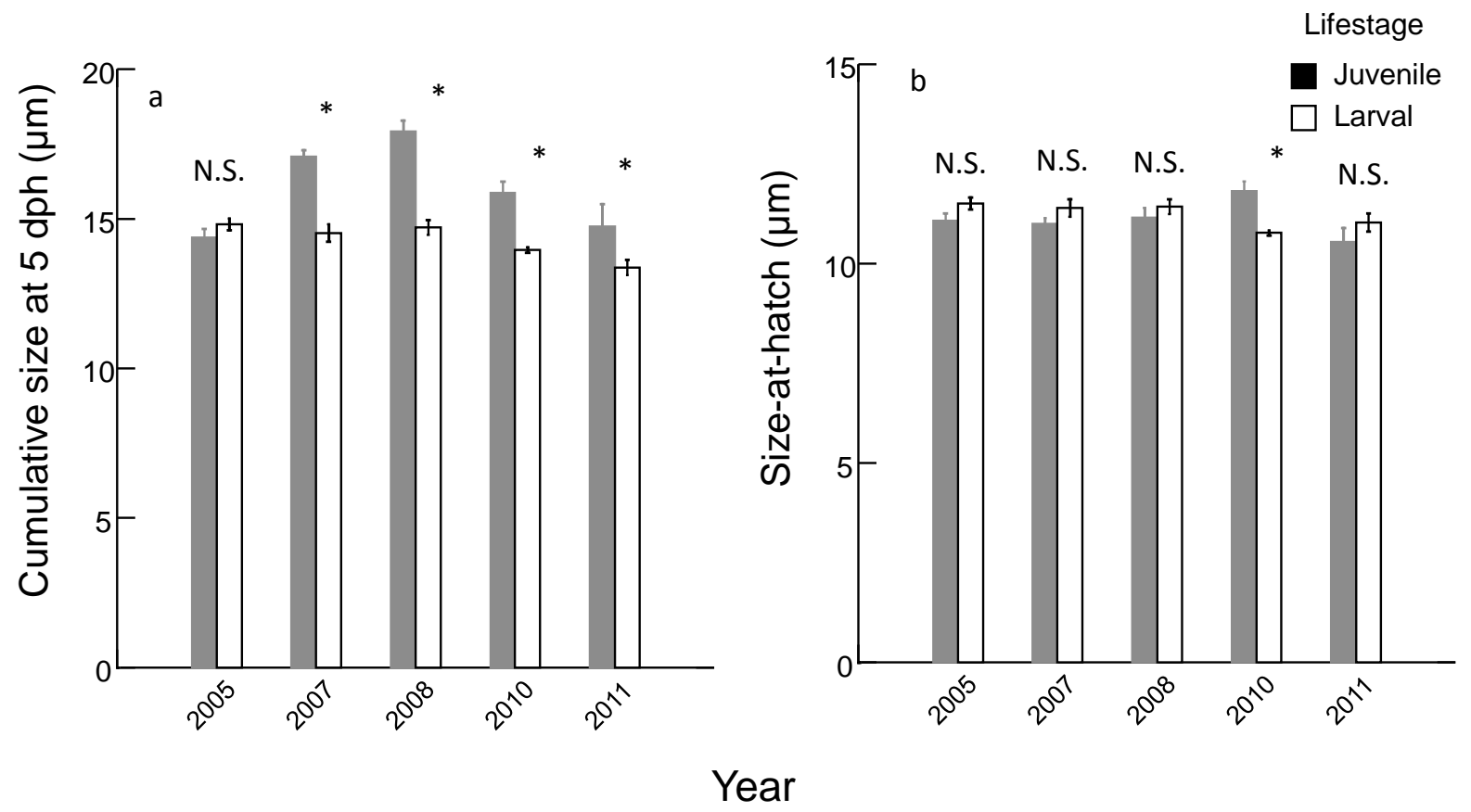


Fig. 4
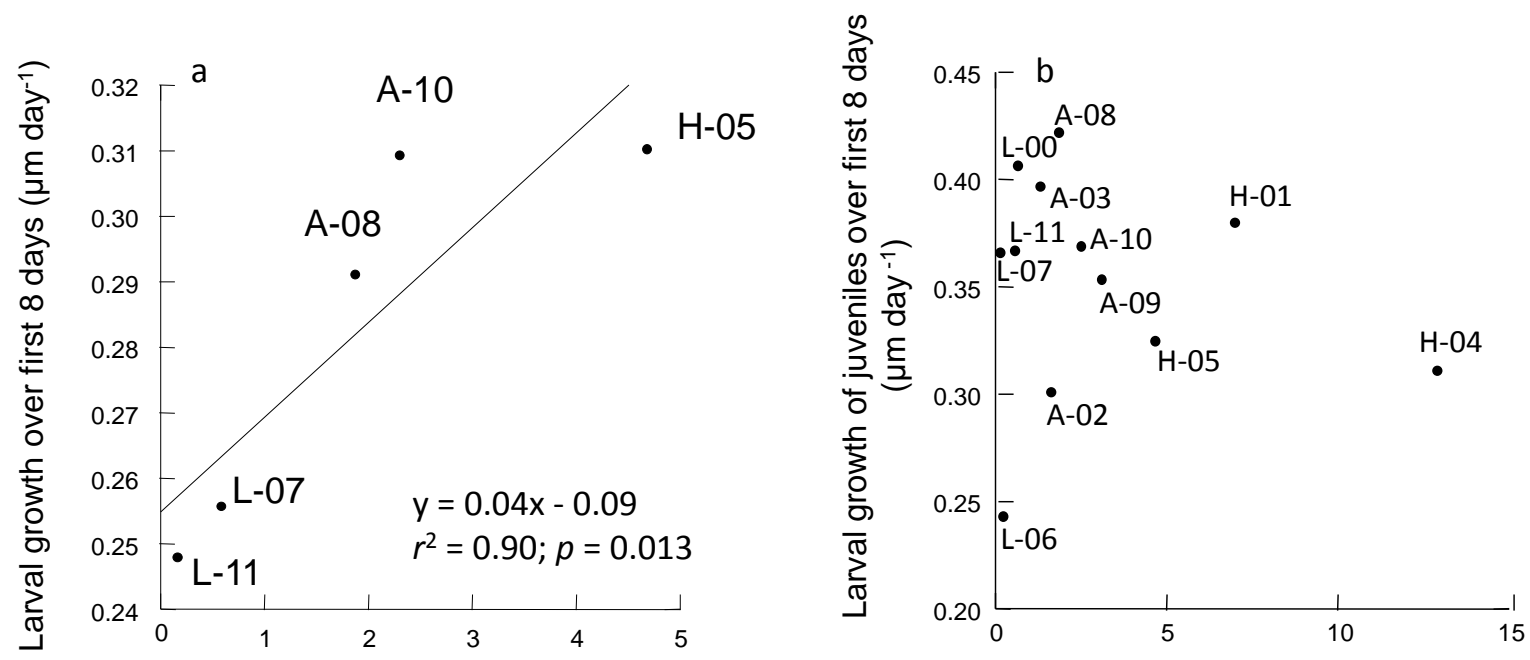

Juvenile density $\left(x 1000 \mathrm{~m}^{-2}\right)$ 
Fig. 5
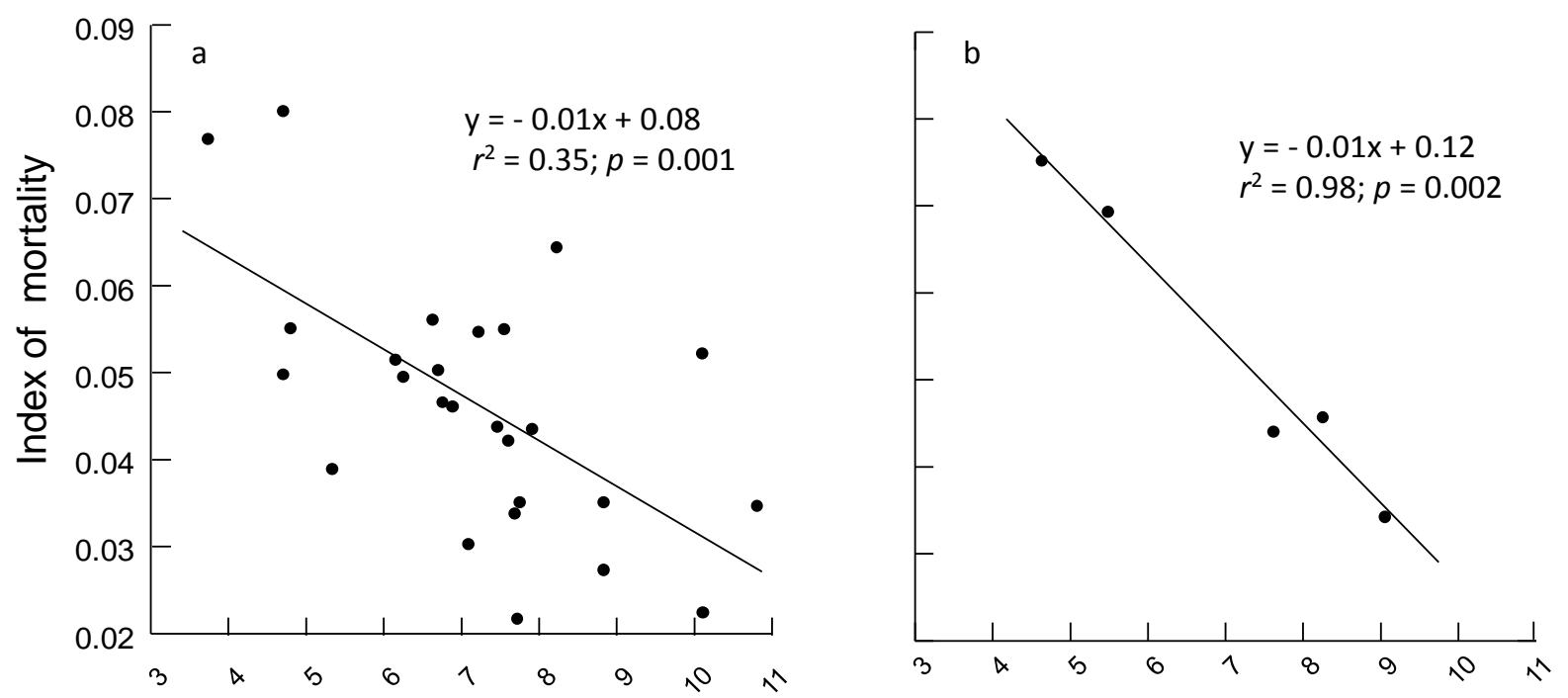

Per capita prey availability $+1\left(\mathrm{~m}^{-2}\right)$ 
Fig. 6

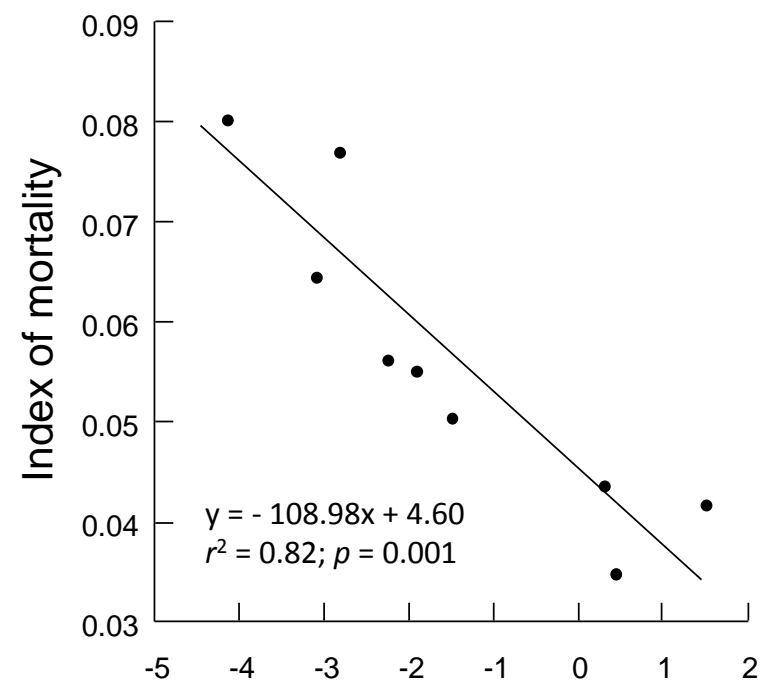

Magnitude of selective mortality $(\mu \mathrm{m})$ 
Author contributions: GPJ and PAH conceived and designed sampling protocol. PAH, FWWM, HMM collected data. HMM, FWWM, SES analysed the data. HMM and FWWM wrote the manuscript; other authors provided editorial advice. 


\section{University Library}

\section{- M M N E R VA A gateway to Melbourne's research publications}

Minerva Access is the Institutional Repository of The University of Melbourne

Author/s:

Murphy, HM;Warren-Myers, FW;Jenkins, GP;Hamer, PA;Swearer, SE

Title:

Variability in size-selective mortality obscures the importance of larval traits to recruitment success in a temperate marine fish

Date:

2014-08-01

Citation:

Murphy, H. M., Warren-Myers, F. W., Jenkins, G. P., Hamer, P. A. \& Swearer, S. E. (2014). Variability in size-selective mortality obscures the importance of larval traits to recruitment success in a temperate marine fish. OECOLOGIA, 175 (4), pp.1201-1210. https:// doi.org/10.1007/s00442-014-2968-9.

Persistent Link:

http://hdl.handle.net/11343/282551 